\title{
Policy Entrepreneurship and Policy Transfer: Flood Risk Governance in Northern Sweden
}

\begin{abstract}
Central to policies relating to risk governance at the regional and local levels is the interaction between the public and private sectors also referred to as networked governance. At the same time, the role of political actors in general and policy entrepreneurs in particular, in terms of policy change, has gained considerable traction in recent policy scholarship. The purpose of this study was to investigate the change in governance arrangements resulting in the formation of a coordination network in regional flood risk management-the first of its kind in Sweden. Our research is guided by the following questions: first, would the policy change (the establishment of the networks) have taken place if a policy entrepreneur were not part of the policy transfer process? Second, what is the role of policy entrepreneurship in the implementation of the policy after its nationwide adoption? Third, what other factors played a role in the variation of the results in the implemented policy that is, the enforced networks? We find the role of a policy entrepreneur key in the policy transfer from the regional to the national level. In order to investigate the resultant networks, we draw from B. Guy Peters (1998) and his conceptualization offactors which affect the politics of coordination. In addition to the presence of a policy entrepreneur, we compare: (i) pluriformity of network members; (ii) member interdependence; (iii) redundancy of structures, and (iv) degree of formality (in terms of meetings). Our findings suggest that entrepreneurs contribute to the variation in the functionality of the enforced river groups, though other factors play a significant role as well. Most importantly, perhaps, we did not identify entrepreneurs in any of the river groups which were not functional.
\end{abstract}

KEYWORDS: Policy entrepreneurs, policy transfer, networks, risk governance, implementation, coordination

RECEIVED 11 August 2016; ACCEPTED 14 December 2016.

\section{INTRODUCTION}

Climate change is expected to result in more extreme weather events worldwide, as well as a rise in sea level (IPCC, 2014), while a recent study posits that human activity has damaged the planet's biodiversity so gravely that we have entered an era of the 'sixth mass extinction' (Ceballos, Ehrlich, Barnosky, García, Pringle, \& Palmer, 2015, p.1). Even in countries such as Sweden where flooding has not historically been an acute problem, severe flooding instances during the past two decades have made it imperative that there be a mechanism for coordination for flood risk management. The main causes of flood in Sweden are snowmelt and torrential rains. Every spring, snowmelt causes regular high flows and small floods in the north of the country. Occasionally, torrential rains cause much larger flooding (Swedish Meteorological and Hydrological Institute, SMHI, 2015)

The purpose of this study is to investigate the organizational change that resulted in the formation of the 'Coordination Group for Information at High Flows etc.' (hereinafter referred to as the 'Coordination Group'), which was the first coordinating body of flood risk management in Sweden and sparked the formation of several new arrangements of collective action thereafter. What is more, this paper contributes to the policy transfer literature by interrogating the coercive transfer process of the policy innovation resulting in its nation-wide adoption.

We do this through the framework of policy entrepreneurship and specifically by asking the following questions: first, would the policy innovation have taken place if a policy entrepreneur were not part of the process? Second, what is the role of the entrepreneurial actors in the implementation of this policy after it was adopted nationally? Third, what other factors played a role in the variation of the result in the implemented policy—the enforced networks?

1 Evangelia Petridou, Pär M. Olausson: Mittuniversitetet, Sweden. Emails: evangelia.petridou@miun.se, par.olausson@miun.se 
In this study, therefore, we investigate policy entrepreneurship as exercised by public officials that it to say, bureaucrats. Bureaucracy has had negative connotations and has been code for slow, ineffective, risk averse, leviathan-size organizations even before the Osborne and Gaebler 1992 polemic, sensationalized in the media in regular intervals in the US and Europe alike. We challenge this notion, and following partly Windrum (2008), we investigate the mechanisms of policy innovation in the field of flood risk governance. On the one hand, we unpack the policy transfer mechanism by analysing how the new policy was adopted. On the other hand, we interrogate the processes which took place when administrative/organizational innovations were transferred from the regional level through the national level and then in turn dispersed broadly to all subnational regions with differentiated local contexts, paying special attention to the role of policy entrepreneurs.

Therefore, and to investigate this, we build on the criteria outlined by Peters (1998) to form our hypotheses, presented later in this paper. These are:

- Pluriformity: the degree of network integration

- Interdependence: the degree to which the members of a network are dependent on each other

- Formality: the degree of formalization of interactions among network members

- Instruments: what kind of tools (planning, formal regulations, contracts, meetings) are used to achieve coordination?

\section{THEORETICAL ASSUMPTIONS}

This section outlines the theoretical blocks of our argument and includes a discussion on policy transfer, network governanceespecially flood risk governance—-policy entrepreneurship and the policy problem at hand.

\section{Policy Transfer}

Policy transfer is 'an action oriented activity' (Evans \& Davies, 1999, p.366), a term that 'refers to a process in which knowledge about policies, administrative arrangements, institutions etc. in one time and/or place is used in the development of policies, administrative arrangements and institutions in another time and/or place' (Dolowitz \& Marsh, 1996, p.344 see also Dolowitz, 2000), 'both within and between different political contexts' (Benson and Jordan 2011, p. 367). Terms similar to policy transfer are lesson drawing and emulation; Rose (1991) uses the terms policy transfer and lesson drawing interchangeably, whereas Dolowitz and Marsh (1996) differentiate between the two on the basis of intent. Lesson drawing implies a conscious and voluntary decision to adopt a policy from another place or time, whereas policy transfer may very well take place through coercive mechanisms. We choose to employ policy transfer and not the closely related literature of policy diffusion because the policy transfer agency favours agentic explanatory factors and the use of qualitative methods in case study research (Marsh \& Sharman, 2009). By and large, policy transfer takes place when there is dissatisfaction with existing policies leading to a change (Marsden \& Stead, 2011; Pierson, 2003; Rose, 2005). Increased ease of flow of information in flatter network governance arrangement facilitates policy transfer mechanisms in governments, horizontally and vertically, across and within countries.

At the same time, we have to acknowledge that policy transfer is inherently complicated and uncertain. Even initiatives directly copied from one jurisdiction to another end up retaining elements already existing in the receiving jurisdiction. What is more, as with any policy, failure can occur at any stage-from the initial formulation to implementation. It follows then that it is methodologically difficult to assert to what degree transfer has occurred, as well as to differentiate between transfer and endogenous policy processes (Pierson, 2003; Smith, 2004).

\section{Networks}

These processes take place in the context of multi-level governance, where, 'while governments clearly remain in the business of governing, they do so increasingly by experimenting with new modes of governance that share authority, use a variety of novel policy instruments and result in new kinds of institutions' (Capano, Rayner, \& Zito, 2012, p.56). The number of people (actors) and 
institutions involved in a commons problem coupled with varied degrees of interdependencies between them make for a complex social and political governance framework. Increasingly, this interaction takes place in the form of networks and the scholarship examining the function and structure of networks from theoretical and empirical perspectives burgeoned in the 1990s. Bogason and Toonen (1998) took stock of the state of public administration remarking on the salience of polycentricity, networks and the policy trend in Public Administration. Drawing from Ostrom, Oakerson and Parks (2011) define polycentricity as a '...process of decision making where multiple independent actors interact to produce an outcome that is commonly valued...' and a ' ...pattern of governance that emerges from the interactions of multiple independent centres of authority...' (p.153). Rhodes argued against the existence of a monolithic power centre and in favour of polycentric arrangements of power managed in network arrangements, in which the actors come together and use one another's resources (Rhodes, 1997; Evans \& Davies, 1999; Sørensen \& Torfing, 2005). Important features of networks are self-organization, interdependence between actors and resource exchange. Resource utilization drives networks; in other words, Actor A has something that is valuable to Actor B, and vice versa. Additionally, networks are characterized by significant autonomy from the state (Rhodes, 1997).

\section{Flood Risk Governance and the Policy Problem}

In governance structures network negotiation is salient to reaching a policy outcome, which may very well include 'soft-regulation' approaches (Boholm, Corvellec, \& Karlsson, 2012). Risk governance specifically, which is part of the object of study in this paper, is about both the structures and the policy process that prescribe collective action of any group tasked with regulating, reducing and controlling risk problems. In the past two decades, in line with the shift to the governance mode of thinking outlined above, the responsibility of handling risk collectively has shifted from central governments with hierarchical structures, to multi-governance structures including multi-actor alliances with a blend of governmental, quasi-governmental and private actors (Renn, Klinke, \& van Asselt, 2011). In a case study of the Göta River in the southwestern part of Sweden, Boholm, Corvellec and Karlsson (2012) emphasize the fluidity of the meaning of risk when connected to a river. The authors find that the river is assigned a different primary meaning depending on whom one asks. Its main purpose could be to facilitate transport, provide electricity or drinking water. Additionally, 'definitions, priorities, and responsibilities must be flexibly negotiated by actors who keep meeting on the occasion of one risk issue or another, but with different roles and formal responsibilities' (p. 12).

When it comes to assigning meaning to the river, this fluidity is also relevant for the current study. The multitude of actors in the different river groups, as well as the multidimensionality of flood risk governance itself, point to the policy problem of coordination, as articulated in a recent work by Peters (2015). Though Peters was primarily referring to the interdependence of public policies and the need for coordination if they are to be effective individually and as a whole, flood risk governance and river management by networks, face the same conundrums. First, there is technical complexity engendered by difficulty in pinpointing the causes of a problem or even agreement on what the definition of a problem might be. That could be different between a dam owner and a public official. Political complexity is the result of different actors being involved.

Understanding the mechanisms of cooperation within horizontal governance and the role of (entrepreneurial) agency in this cooperation can help us solve the policy problem and achieve a more effective (policy) solution. We investigate agency using the policy entrepreneurship (PE) lens.

\section{Policy Entrepreneurship and the Entrepreneur}

Oakerson and Parks (1999) identify initiative takers in polycentric orderings as 'public entrepreneurs' and argue that the more the possible sources of initiative, in other words, the more the possible decision loci, the better the chances for public entrepreneurship to occur. Policy entrepreneurs are also identified by Dolowitz and Marsh (1996) as policy transfer agents.

The policy entrepreneurship literature has made considerable progress and has moved away from the image of the policy entrepreneur as a rational actor; rather the metaphor of the policy entrepreneur allows us to understand the agentic capacity of individuals in the messiness of the non-linear policy process. A policy entrepreneur is 'a special kind of actor, embedded in the 
sociopolitical fabric, who is alert to the emergence of opportunities and acts upon them; he or she amasses coalitions for the purpose of effecting change in a substantive policy sector, political rules or in the provision of public goods' (Petridou, Narbutaite-Aflaki, \& Miles, 2015, p. 1). Initially one of the structural components of the Multiple Streams Approach (MSA), policy entrepreneurs are recognized as a component of all major policy process theories (Mintrom \& Norman, 2009). In a seminal 2009 article, Mintrom and Norman 'provide both a clear definition of what a policy entrepreneur is and also a clear framework for describing the success or failure of a policy entrepreneur' (Hammond, 2013, p. 120), whereas in a recent review, Petridou (2014) shows the evolution of the policy entrepreneur(ship) as a comprehensive meso-level framework. Policy entrepreneurship has provided insights in such diverse sectors as Dutch water management (Brouwer \& Biermann, 2011), local economic development and growth policies (Schneider, Teske, \& Mintrom, 1995; Verdujn, 2015), educational policy (Mintrom, 2000), stem cell research regulation (Mintrom, 2013; 2015), and international relations (Blavoukos \& Bourantonis, 2011; 2012; David, 2015; Miles, 2015) among others.

Policy entrepreneurs (political or public, we use the terms interchangeably here, for a justification see Petridou, NarbutaiteAflaki, \& Miles, 2015) can be found anywhere: they might work in the public or private sector, or for a non-profit organization. They may or may not hold a formal position of leadership. Furthermore, an entrepreneur is a function rather than a set of personal attributes. Regardless of the institutional context of the policy entrepreneur, a set of assumptions is common to entrepreneurial behaviour across the board. First, policy entrepreneurs are creative and insightful in that they have a vision of how their proposals will affect the policy debate in the long run. Secondly, policy entrepreneurs are socially sensitive, and perceptive enough to be able to view problems from many different angles. These two assumptions relate to previously articulated theories of policy/public entrepreneurs and the idea that they have to be alert in order to be able to discern emergent problems. Thirdly, policy entrepreneurs must be able to move in and out of a variety of social and political settings—in other words, they must be networked. Fourthly, policy entrepreneurs must be able to argue persuasively; in other words, they must be able, through effective rhetoric, to transform social perceptions. By reframing an issue 'the entrepreneur generates "needs" and then meets those needs with specific responses' (Scheider, Teske, \& Mintrom, 1995, p. 43). A number of recent studies examine the policy entrepreneurship of high profile actors, such as heads of state (Blavoukos \& Bourantonis, 2012; David, 2014; 2015; Hay, 2002; Miles, 2015) or important private sector actors (Mintrom, 2013; 2015), whereas the entrepreneurial actions of mid-level bureaucrats has been under researched.

\section{Hypotheses}

The Swedish river groups provide a fruitful context for a comparison based on the principles outlined by Peters (1998). The Swedish system with its consensual sensibilities based on broad inclusion (Petridou, 2017) places all the networks in (at least on paper) a nonhierarchical environment allowing for Peters' factors to be examined under the same broad decision-making conditions. Additionally, as reported elsewhere (Olausson \& Nyhlén, forthcoming), the networks exhibited certain characteristics that supported the choice of Peters' theoretical framework regarding the comparison. First, five of the river groups (the ones controlled by the northernmost county of Norrbotten) displayed low levels of functionality. They were markedly informal in that they had no regular meetings and their cooperation could be considered ad hoc. Redundancy, in the form of additional networks the partners could tap into if needed, is also a parameter featuring in six of the seven remaining river groups. Finally, the composition of each river group, which speaks to both pluriformity and member interdependence has resulted in a qualitative difference in focus: all the river groups that are coordinated by the county of Jämtland have a planning focus, whereas the group for Ljungan River has a more technical focus. The latter, for example has developed an early alarm system (Olausson \& Nyhlén, forthcoming).

Based on this, we hypothesize the following:

(i) More pluriformity leads to better coordination

(ii) The greater the interdependence of the members of the network, the greater the coordination of the network

(iii) If policy entrepreneurs are involved in keeping the network together, the coordination level of the network is higher

(iv) The greater the redundancy of structures, the lesser the coordination of the network

(v) The greater the degree of formality of the network, the lesser the coordination of the network 


\section{METHOD}

Data for this study were collected through interviews and document analysis. Semi-structured interviews were conducted at the interviewees' work place, lasting an average of about an hour. All interviews were recorded, transcribed and analysed for content with Atlas.ti. We conducted 10 elite interviews (in one instance we interviewed two informants together) with officials in central positions within the river groups: a politician, individuals involved in the wider activities of the river groups, and the chair of the dam owners' association at the time the Coordination Group was formed. The documents consisted of minutes taken during network meetings, as well as the governmental document calling for the establishment of coordination networks nationwide.

In line with case studies on policy entrepreneurship, we first identified the policy entrepreneurs ourselves (see for example, David, 2015; Mintrom, 2013; MacDonald, 2015; Meydani, 2009; 2015). This is the case even in studies involving large numbers of policy entrepreneurs (see Brouwer \& Huitema, 2015), though Mintrom's (2000) large N study relied on clerks identifying the policy entrepreneurs thus eliminating the attendant bias. What is more, one of the questions asked of all interviewees was whether they could point to one specific individual as a main driving force behind the salience of the network in the minds of its members in order to confirm our own judgement.

The idiosyncrasies of this research allowed us to contribute to the policy transfer scholarship specifically regarding the way endogenous factors (Pierson, 2003) contribute to the divergent ways different regional groups within the same country implement a policy. As we will explain in a later section, the policy transfer process at the policy formulation stage was rather straightforward. Notable, however, is the divergence in implementation and the mixed results observed in the organization of the river groups.

To this end, we employed a most similar systems design rationale (Gerring, 2008; Peters, 1998) on the 12 river groups in the north of Sweden. The fact that all the river groups were in Sweden controlled for differences in the system of governance. Furthermore, we limited our cases in the north of the country in order to make them as comparable as possible, controlling for geography and demographics, as the entire area of study belonged to the sparsely populated European northern periphery on either side of the Arctic Circle (for a map and population information, please see www.SCB.se). Drawing from Smith (2004), we tested the hypothesis that endogenous factors (which we identified through our data collection) contribute to the variance of implementation of the transferred policy. In an attempt to boost construct validity, we employed investigator triangulation, with each of the two investigators analysing the data separately (Patton, 1987; Yin, 1994). Table 1 shows the total number of cases (river groups) used in this study.

Tab. 1: River Groups

\begin{tabular}{ll}
\hline River Group & County in charge \\
\hline Torne älv/Maunio älv/Lainio älv/ Vittangiälven/Rautasälven & Norrbotten \\
\hline Kalixälven/Kaitum älv/ Tärendöälven & Norrbotten \\
\hline Råne älv & Norrbotten \\
\hline Lule älv & Norrbotten \\
\hline Pite älv & Norrbotten \\
\hline Skellefte älv & Västerbotten \\
\hline Umeälven/Vindelälven & Västerbotten \\
\hline Ångermanälven/Faxälven/ Fjällälven & Västernorrland \\
\hline Järpströmmen/Indalsälven & Jämtland \\
\hline Ljungan/Gimån & Jämtland \\
\hline Ljusnan/Voxnan & Gävleborg \\
\hline Dalälven & Dalarna \\
\hline
\end{tabular}

Source: Olausson (2012) 


\section{THE SWEDISH CASE}

Because of the climate, geography and demographics of Sweden, damage from flooding has generally been markedly less extensive than the rest of the world. A large number of rivers ( 75 percent) are dammed for the purpose of hydroelectric energy production. All dams in Sweden are privately owned and their activities are regulated by the Water Court (Vattendomsto) in contrast to those in the US, for example, where just over 56 per cent of dams are listed as being privately owned, whereas the bigger ones are stateowned (FEMA, 2015). It also has to be noted that these dams are not flood control dams, rather they are built for the production of electricity. As flooding is not seen as a major cause of accidents and loss of life, there has been rather limited public oversight of dams compared to other Western countries, as well as compared to other areas within Sweden, such as nuclear power plants, airport and railways, which are perceived as more dangerous in the sense that any accident can cause great public harm (SOU, 1995, p. 40).

In May 1994, following the severe floods of the previous year, the national government ordered an investigation into dam safety and protection against flooding. Here, we must note the importance of commissions of inquiry as a tool of policymaking in the Swedish context, which is considered to be deliberative, rationalistic, open, and consensual (Anton, 1969; Petersson, 2016). What is more, strong emphasis is put on the preparatory stages of policy making, most commonly taken up by commissions of inquiry. These are committees with a legal status similar to other governmental agencies, set up to investigate a particular problem. Parliamentary approval is not required and considerable centralized political control is exercised on them (Petersson, 2016).

The main question the investigation was tasked to answer was - how the state can act more proactively and with better competence both at the regional and at the national levels regarding the above issues (SOU, 1995, p. 40). Though the investigation found no technical problems with dam safety, it also pointed out the need for coordinating bodies at the regional (county) as well as at the national level. Dam owners are private companies; their goals are market driven and safety is not their primary concern, which underlines the need of some sort of public oversight and coordination among the actors involved in flood risk governance.

One of the recommendations of investigation was to form a regional coordinating body at the county level for each large river system. Notably, this body could not assume responsibility that rested with another authority; in effect its authority would be to bring together the different stakeholders - including the municipalities and their emergency services, dam owners and any other organizations regarding water management and if needed, SMHI. Such a move was in line with a new theme of reform that surfaced in the 1990s, the theme of collaboration between public and (quasi)private organizations (Niklasson, 2016).

In accordance with the large leeway provided to agencies, municipalities and county organizations in Sweden, no strict instructions were given as to the composition, the organization or the functionality of these river groups. The original Coordination Group consisted of representatives of the County Administrative Boards of Jämtland, Västernorrland, Västerbotten, and Gävleborg; the dam owners for the Ume, Ångerman, Indals, Ljungan and Ljusnan rivers; the Rescue Service in Östersund (county of Jämtland); the emergency services (SOS-alarm AB); SMHI, and the Armed Forces. Several other actors joined the group later, including the County Administrative Board of Dalarna, the Swedish Transport Administration, the Dal River water regulation company, and the Rescue Services in Jämtland and Medelpad (Agreement 1 1995; Agreement 2 2005; Olausson and Nyhlén forthcoming). Generally, the responsibility for risk assessment and management in Sweden rests with the municipality, but the counties can act as a liaison to the national government with a coordinating function, and indeed the coordination of each river group was the responsibility of the county.

Broadly speaking, research on flood risk governance in Sweden is limited, however, Fell (2008) examined the Energy Agency's program Sustainable Municipality. She argues that the network governance must be characterized by equality between the parties and mutual trust. Commons-problem solving necessitate a relationship built on negotiation and not by competition among asymmetric network positions. The goal for the participants must be to increase their capacity to solve the commons problems through networking (2008, pp. 10-12). Despite the relative lacuna in flood risk governance research in Sweden, Nyberg (2008) shows (as opposed to SOU, 1995 , p. 40) that Sweden experienced several major floods in the 1980s that often caused great damage and resulted in huge societal costs.

Also relevant to this paper is the work by Hedelin and Hjerpe (2014), examining the collaborative arrangement of the Ljusnan River group. The authors employ a two-by-two matrix assessing whether the benefits users derive from the collaborative arrangement (i.e., the river group) are in sync with the benefits the providers feel they produce. Hedelin and Hjerpe (2014) aim at providing a more holistic picture through an in-depth qualitative assessment, which exposes mismatches between provided benefits and needed benefits, as well as between provided benefits and utilized benefits. This work has the added normative goal to increase the efficiency of such collaborative arrangements. 


\section{ANALYSIS}

Examining the transfer of policy within the same nation-state has the advantage of shedding light on how a policy is uploaded nationally and then downloaded regionally. It is in this context that we analyse: (i) the creation of the Coordination Group, (ii) the transfer of this new collective action arrangement from the regional to the national level, and (iii) the variations in the implementation of this policy. In doing so, we attempt to answer the questions put forth earlier in this paper.

\section{Policy Entrepreneurship}

After the severe flooding in 1993 Anders Lindh, the head of the Vattenregleringsföretagen (Water regulation corporations) stationed in Jämtland, contacted the then county governor Sven Heurgren with the idea that something had to be done to address the lack of coordination. When asked what made him start the process, and specifically why then, he simply said that it was obvious to him that intervention was needed. Heurgren then tasked Staffan Edler, a public official to 'make sure that this worked next time' (Respondents 9 and 10, 2015). The handling of flooding was inadequate with gaps in communication and pronounced lack of coordination. Earlier attempts at coordinating the multiple agencies involved in crisis management had failed. The 1993, flooding presented an opportunity to affect change by underlining the inadequacies of existing institutional arrangements. Crises as decision arenas have been well documented in the literature (Miles \& Petridou, 2015). Dror (1993, p. 13) recognizes opportunities crises present due to 'the softening of institutional rigidities, which consequently open up new vistas for political and social feasibility', in other words, Kingdon's window of opportunity that becomes a propitious time for policy change (Kingdon, 1984). Lindh and Edler, the public official instrumental to the creation of the Coordination Group acted as policy and bureaucratic entrepreneurs respectively because of the following strategies:

First, the failure in dealing with the flooding presented an opportunity. According to the literature, as mentioned elsewhere in this paper, recognizing opportunities and taking advantage of these opportunities are core tenets of policy entrepreneurship. Lindh saw a need that had to be met and acted on it. Edler acted entrepreneurially, with political support, to implement the idea of a coordinating network. However, we must note that the opportunities presented to bureaucratic entrepreneurs are of a different nature than the ones presented to politicians or members of public. Such entrepreneurial actors can incorporate shifts in public opinion or crises in their rhetoric in an effort to create a momentum towards their proposed solution. The opportunities presented to bureaucrats are integral to the context of their professional activities, and their ability to take advantage of these in practice depends on the space they have in which they are allowed to take initiatives and work towards realizing these initiatives. This space is created by the political support offered to these bureaucrats.

Secondly, Edler had a wide network in place already and was part of the regional crisis management structure due to his formal position as a public official at the county of Jämtland. He and Lindh were able to get the dam owners on board. Their umbrella organization was responsible for the regulation of water flow for hydropower in all six rivers between Umeälven to the north and Dalälven to the south ${ }^{2}$. It consisted of the water corporations owning dams for hydroelectric power in these rivers (Vattenregleringsföretagen, n.d.). Lindh became the chairman of the Coordination Group and Edler the secretary and the cooperation between the two that was crucial. The dam owners were the most important actors; their participation was essential to the success of this Coordination Group.

Third, Edler had not only the perseverance necessary to realize the idea of the Coordination Group, but also a practical mind and hands-on problem solving skills to overcome hindrances along the way. He tells the story of a conference call meeting in the 90 s when the telephone equipment available could handle only up to seven participants. There were more than seven participants in this meeting, so they bought two conference phones, speakers and microphones and placed them across from each other. 'The sound was bad', Edler says, 'but it worked. It felt afterwards that we were being pioneers!'

Fourth, the importance of a team is evident. Edler talks about 'reinventing the wheel a few times' and how they constantly felt they broke new ground with this group. At the same time, he did not see himself as the creator of the network or even the most important actor. 'I don't want to claim that this is a job for one person. I took the initiative to build this but for sure we felt it was

2 These six rivers are: Umeälven, Ångermanälven, Indalsälven, Ljungan, Ljusnan, and Dalälven. 
needed... [T]here were the right people at the right place... and we had a lot of practical people who solved problems instead of creating them because one can set up inquiries for things and investigate and investigate and continue investigating, always finding problems that have to be solved before anything can start.' (Respondents 9 and 10, 2015). Lindh, in order to facilitate trust among the members of the network, instituted retreats at regular intervals where people could meet and 'have fun and get to know each other'. (Respondent 11)

Finally, timing, or 'the right place at the right time' element of policy change, echoes Kingdon (1984) and Zahariadis (2007), as well as more recently in foreign policy making, David $(2013 ; 2015)$. However, if the analysis above is used to answer the question on whether the Coordination Group would have taken place without the entrepreneurs, then we must conclude that the network would not have taken off the ground if it were not for them, and if it had, it would not have been successful.

\section{Policy Transfer}

Evans and Davies (1999) developed multi-stage models of policy transfer, depending on whether the process is voluntary. Regardless of this, they identified stages in which a transfer network emerges. Key actors interact in forums organized for this purpose, the policy is evaluated, and a decision is made. We argue that the Swedish policy making feature of setting up commissions of inquiry as a means of drafting a bill compresses these stages considerably. In this instance, a commission was set up in May 1994, to investigate issues of dam safety and protection against flooding. The crisis of the floods of the previous summer had brought the issue in the forefront of the discourse and warranted investigation. The members of the inquiry team were a mix of scientists, bureaucrats and politicians. One of them was Anders Lindh, the executive director of the Water Regulation Corporations, chair of the Coordination Group. In the process of the 10-month long investigation, a questionnaire was sent out to all the counties and it soon became apparent that the only collective arrangement in existence was the Coordination Group. The report proposes that such groups (networks) be established nation-wide (SOU, 1995, p. 40).

Such commissions of inquiry themselves become the transfer network, the forum for interactions, place for negotiations and lesson learning. Though any negotiation processes might be opaque, this report provides an insight as to the search method - a survey - and the policy entrepreneur/agent of transfer - the chair of the Coordination Group, who also served in the commission.

\section{Implementation and varying results}

The commission on dam safety and protection against flooding (River Safety Investigation, SOU, 1995, p. 40) suggested the formation of river groups for all major rivers in Sweden and in 1997 the Swedish Rescue Services called for the formation of such networks in both regulated and unregulated rivers. The County Administrative Boards were put in charge for establishing the networks with very few guidelines from the national government as to what these networks were supposed to look like as mentioned elsewhere in this paper. Today there are 30 river groups in Sweden spread all over the country, with the exception of the counties of Skåne, Blekinge, Gotland and Östergötland, where there are no river groups. Twelve of the 30 river groups are found in the northern parts of Sweden, which is also where some of the largest rivers are. Incidentally, these groups, together with the river group for Klarälven/Göta älv, comprise the River Network, a collaborative arrangement that in 2014 replaced the original Coordination Group.

The overarching purpose of the river groups was to increase the levels of coordination and collaboration among the various stakeholders. In practice, this implies open communication channels facilitating information flows for the purpose of a common strategy regarding flood risk management. Network members could decide on the composition, scope, instrument and focus of the network, though as mentioned earlier, the actor in charge of each network was the county. The findings of the comparison are summarized in Table 2 .

The five river groups controlled by the northernmost county of Norrbotten (see Table 2) had very few members (low pluriformity), low member interdependence, and most importantly, other networks to rely on for flood risk management - high redundancy. The coordinator responsible for the five networks argued against the need for river groups for two reasons: first, there were no water ponds along the four unregulated rivers under its jurisdiction, and therefore, no possibility to control the water level in this way during high flows. What is more, in the fifth river, which was regulated, only one water company was involved and that company had developed 
Tab. 2: River Group Comparison Findings

\begin{tabular}{|c|c|c|c|c|c|c|c|c|}
\hline River Group & $\begin{array}{l}\text { County in } \\
\text { charge }\end{array}$ & $\begin{array}{l}\text { Plurifor- } \\
\text { mity }\end{array}$ & $\begin{array}{l}\text { Member } \\
\text { Interdepen- } \\
\text { dence }\end{array}$ & $\begin{array}{l}\text { Policy Entre- } \\
\text { preneurs }\end{array}$ & $\begin{array}{l}\text { Redun- } \\
\text { dancy }\end{array}$ & $\begin{array}{l}\text { Degree of } \\
\text { formality }\end{array}$ & $\begin{array}{l}\text { Point in } \\
\text { time }\end{array}$ & $\begin{array}{l}\text { Coordina- } \\
\text { tion }\end{array}$ \\
\hline $\begin{array}{l}\text { Torne älv/Maunio älv/ } \\
\text { Lainio älv/ Vittangiälven/ } \\
\text { Rautasälven }\end{array}$ & Norrbotten & - & - & - & + & - & later & - \\
\hline $\begin{array}{l}\text { Kalixälven/Kaitum älv/ } \\
\text { Tärendöälven }\end{array}$ & Norrbotten & - & - & - & + & - & later & - \\
\hline Råne älv & Norrbotten & - & - & - & + & - & later & - \\
\hline Lule älv & Norrbotten & - & - & - & + & - & later & - \\
\hline Pite älv & Norrbotten & - & - & - & + & - & later & - \\
\hline Skellefte älv & Västerbotten & + & + & - & - & - & earlier & + \\
\hline Umeälven/Vindelälven & Västerbotten & + & + & + & - & + & earlier & + \\
\hline $\begin{array}{l}\text { Ångermanälven/Faxälven/ } \\
\text { Fjällälven }\end{array}$ & Västernorrland & + & + & + & - & + & earlier & + \\
\hline Järpströmmen/Indalsälven & Jämtland & + & + & + & - & + & earlier & + \\
\hline Ljungan/Gimån & Jämtland & + & + & + & - & + & earlier & + \\
\hline Ljusnan/Voxnan & Gävleborg & + & + & + & - & + & earlier & + \\
\hline Dalälven & Dalarna & + & + & - & - & + & earlier & + \\
\hline
\end{tabular}

Source: Authors

its own risk assessment and coordination plan in the event of high flows (see also Olausson \& Nyhlén, forthcoming). This meant that county did not see the need for additional networks, and therefore, did not make use of them. They hardly had any meetings at all and the river groups only existed on paper. Additionally, no policy entrepreneurs were identified from the interviews. None of these groups made any substantive decision or was an active player in flood risk management. Finally, the county in charge of all these groups (Norrbotten) had not been involved at all with the original Coordination Group.

An examination of the river groups administered by the counties of Västerbotten, Västernorrland, Jämtland, Gävleborg, and Dalarna reveals a more nuanced picture. They are more coordinated (in comparison with the five groups previously discussed) with increased levels of functionality in the sense that they have mechanisms in place for making decisions to which their members adhere. Their members are more diverse (higher levels of pluriformity), more interdependent, and have formal instruments in place, such as organized meetings. What is more, no other similar structures are in place, which allows for the counties to invest resources into the river groups.

The influence of the Coordination Group in these river groups is hard to be overestimated. All but two of them (Skellefte älv and Dalälven) were part of the Coordination Group, so the policy entrepreneurs that were active in that group were also active in the Umeälven/Vindelälven; Ångermanälven/Faxälven/ Fjällälven; Järpströmmen/Indalsälven; Ljungan/Gimån, and Ljusnan/Voxnan river groups. Interestingly, the interview with the Västerbotten county officials reveals a spillover between the Umeålven/Vindelälven river group and the Skellefte älv river group: the way the network operated was inspired by the work of Anders Lindh and Staffan Edler, the entrepreneurial actors. A similar indirect process is present in the Dalälven river group as well, which joined the Coordination Group at a later time. All these groups had high degrees of pluriformity, member interdependence, and formal instruments, as well as low levels of redundancy. Most of them had direct contact with the entrepreneurial actors, two of them indirectly. 
Our findings confirm four of the five hypotheses put forth earlier in this paper. The fifth suggested that high levels of formality would result in low levels of coordination, whereas we found the opposite. The nuance revealed from this comparison concerns the role of the Coordination Group in the operations of the river groups after they became national policy: the river groups that comprised the original Coordination group had already accepted the process, they understood it, they were familiar with the gains they would get, they saw the point of having a network and even brought in diverse groups, such as the planning department. The river groups that had no contact with the original Coordination Group simply did not see the point. This illustrates the value of informal policy transfer, where the transfer entrepreneurs are at work in the implementation phase in a more indirect capacity.

\section{CONCLUSIONS}

In this article, we set out to investigate the policy transfer process of the river group networks for flood risk governance in Sweden and to investigate the role of policy entrepreneurship in the creation of the original coordination network, the policy transfer itself and the variation in functionality of the ensuing enforced networks. Though policy entrepreneurs are present in five out of the seven networks which increased levels of functionality, we cannot determine a causal relationship between the two. We can, however, say that no entrepreneurs were present in the networks that had lower levels of functionality.

Most importantly, we found that the establishment of the original self-organizing network was facilitated by the cooperation of two entrepreneurial actors, one of which acted as a transfer entrepreneur when he uploaded the policy from the regional level to the national level. Our analysis confirms the counterfactual statement that the Coordination Group would not have transferred from the regional to the national level were it not for the transfer entrepreneur. The success of the Coordination Group, the networking capacities and the prominent position of the entrepreneur allowed for the broader acceptance of these networks as nation-wide flood risk governance arrangements in Sweden. It speaks to the success of the Coordination Group, perhaps, that regional cooperation is at such a level that the group in 2014 was disbanded and was replaced by a network of river groups.

More research is needed to tease out the differences between self-organizing and enforced networks. A fruitful avenue would be comparing the networks with the use of social network analysis, for example, in order to determine the role of each actor.

\section{ACKNOWLEDGEMENTS}

We wish to thank our respondents, without whom this paper would not have been possible. We also thank the anonymous reviewers for their invaluable comments.

\section{REFERENCES}

Agreement 1 (1995) Överenskommelse om att gemensamt inrätta en samordningsgrupp för information vid höga flöden m.m [Agreement to jointly set up a coordination group for information at high flow etc.]. County Administrative Board of Jämtland.

Agreement 2 (2005) Överenskommelse om inrättande av samordningsgrupp för information vid höga flöden m.m. [Agreement on the establishment of the coordination of information at high flow rates, etc.] 2005-06-01. County Administrative Board of Jämtland.

Anton, T. J. (1969). Policy-Making and Political Culture in Sweden. Scandinavian Political Studies, 4, 88-102.

Benson, D., \& Jordan, A. (2011). What Have We Learned from Policy Transfer Research? Dolowitz and Marsh Revisited. Political Studies Review, 9(3), 366-378. doi:10.1111/j.1478-9302.2011.00240.x
Boholm, Å., Corvellec, H., \& Karlsson, M. (2012). The practice of risk governance: lessons from the field. Journal of Risk Research, 15(1), 1-20. doi:10.1080/13669877.2011.587886

Bogason, P., \& Toonen, T. A. J. (1998). Introduction: Networks in Public Administration. Public Administration, 76(2), 205-227. doi:10.1111/14679299.00098

Blavoukos, S., \& Bourantonis, D. (2012). Policy Entrepreneurs and Foreign Policy Change: The Greek-Turkish Rapprochement in the 1990s. Government and Opposition, 47(04), 597-617. Doi:10.1111/j.14777053.2012.01376.x

Brouwer, S., \& Biermann, F. (2011). Towards Adaptive Management: Examining the Strategies of Policy Entrepreneurs in Dutch Water Management. Ecology and Society, 16(4). doi:10.5751/ES-04315-160405 
Brouwer, S., \& Huitema, D. (2015). Policy Entrepreneurs in the Picture: the Who, What, Why and How. Paper presented at the ICPP, Milan.

Capano, G., Rayner, J., \& Zito, A. R. (2012). Governance from the bottom up: Complexity and divergence in comparative perspective. Public Administration, 90(1), 56-73. doi:10.1111/j.1467-9299.2011.02001.x

Ceballos, G., Ehrlich, P. R., Barnosky, A. D., García, A., Pringle, R. M., \& Palmer, T. M. (2015). Accelerated modern human-induced species losses: Entering the sixth mass extinction. Science Advances, 1(5). doi:10.1126/sciadv.1400253

David, C.-P. (2015). How do entrepreneurs make national security policy? A case study of the G.W. Bush administration. In I. Narbutaité Aflaki, E. Petridou, \& L. Miles (Eds.), Entrepreneurship in the Polis: Understanding Political Entrepreneurship (pp. 151-170). Burlington, VT: Ashgate.

David, C.-P., \& Barthe, S. (2013). Entrepreneurs decision making: the example of national security policies of the G. W. Bush administration (2001-2004). Canadian Journal of Political Science-Revue Canadienne De Science Politique, 46(3), 549-574. doi:10.1017/s0008423913000851

Dolowitz, D. P. (2000). Introduction. Governance, 13(1), 1-4. doi:10.1111/0952-1895.00120

Dolowitz, D., \& Marsh, D. (1996). Who Learns What from Whom: a Review of the Policy Transfer Literature. Political Studies, 44(2), 343-357. doi:10.1111/j.1467-9248.1996.tboo334.x

Dror, Y. (1993). Steering Requisites for Crises-Opportunities: On-Going Challenges. Journal of Contingencies and Crisis Management, 1(1), 13

Evans, M., \& Davies, J. (1999). Understanding Policy Transfer: A MultiLevel, Multi-Disciplinary Perspective. Public Administration, 77(2), 361385. doi:10.1111/1467-9299.00158

FEMA. (2015, 01/05/2016). Dam Ownership in the United States. Retrieved from http://www.fema.gov/dam-ownership-united-states

Gerring, J. (2008). Case Selection for Case-Study Analysis: Qualitative and Quantitative Techniques. In J. M. Box-Steffensmeier, H. E. Brady, and D. Collier (Eds.), The Oxford Handbook of Political Methodology (pp. 645-684). Oxford: OUP.

Hammond, D. R. (2013). Policy Entrepreneurship in China's Response to Urban Poverty. Policy Studies Journal, 41(1), 119-146. doi:10.1111/psj.12005

Hays, B. D. (2012). The Curious Case of School Prayer: Political Entrepreneurship and the Resilience of Legal Institutions. Politics and Religion, 5(02), 394-418. doi:doi:10.1017/S1755048312000089

Hedelin, B., \& Hjerpe, M. (2015). Examining the benefits of collaboration: the Provider-User Matrix for collaborative flood risk management illustrated by the case of the Ljusnan River, Sweden. Journal of Natural Resources Policy Research, 7(1), 53-69. doi:10.1080/1 9390459.2014.977539

IPCC (2014) Climate Change 2014: Synthesis Report. Contribution of Working Groups I, II and III to the Fifth Assessment Report of the Intergovernmental Panel on Climate Change [Core Writing Team, R.K. Pachauri and L.A. Meyer (eds.)]. IPCC: Geneva, Switzerland

Kingdon, J. W. (1984). Agendas, Alternatives, and Public Policies. Boston: Little and Brown.
Larsson, T., \& Bäck, H. (2008). Governing and Governance in Sweden Malmö: Student Litteratur.

Macdonald, J. M. (2015). Eisenhower's Scientists: Policy Entrepreneurs and the Test-Ban Debate 1954-1958. Foreign Policy Analysis, 11(1), 1-21. doi:10.1111/fpa.12018

Marsden, G., \& Stead, D. (2011). Policy transfer and learning in the field of transport: A review of concepts and evidence. Transport Policy, 18(3), 492-500. doi:http://dx.doi.org/10.1016/j.tranpol.2010.10.007

Meydani, A. (2009). Political Transformations and Political Entrepreneurs: Israel in Comparative Perspective. New York: Palgrave McMillan.

Meydani, A. (2015). Political Entrepreneurs and Institutional Change: Governability, Liberal Political Culture, and the 1992 Electoral Reform in Israel. In I. Narbutaité Aflaki, E. Petridou, and L. Miles (Eds.), Entrepreneurship in the Polis: Understanding Political Entrepreneurship (pp. 87-102). Burligton, VT: Ashgate.

Miles, L. (2015). Political Entrepreneurship as Painful Choices: An Examination of Swedish (Post)-Neutrality Security Policy. In I. Narbutaité Aflaki, E. Petridou, and L. Miles (Eds.), Entrepreneurship in the Polis: Understanding Political Entrepreneurship (pp. 133-150). Burlington, VT: Ashgate.

Miles, L., \& Petridou, E. (2015). Entrepreneurial Resilience: Role of Policy Entrepreneurship in the Political Perspective of Crisis Management. In R. Bhamra (Ed.), Organisational Resilience: Concepts Integration and Practice (pp. 67-81). Boca Raton, FL: CRC Press.

Mintrom, M. (2000). Policy Entrepreneurs and School Choice. Washington Georgetown University Press.

Mintrom, M. (2013). Policy entrepreneurs and controversial science: governing human embryonic stem cell research. Journal of European Public Policy, 20(3), 442-457. doi:10.1080/13501763.2012.761514

Mintrom, M. (2015). Policy Entrepreneurs and Morality Politics: Learning from Failure and Success. In I. Narbutaité Aflaki, E. Petridou, and L. Miles (Eds.), Entrepreneurship in the Polis: Understanding Political Entrepreneurship (pp. 103-118). Burlington, VT: Ashgate.

Mintrom, M., \& Norman, P. (2009). Policy Entrepreneurship and Policy Change. Policy Studies Journal, 37(4), 649-667. doi:10.1111/j.1541$0072.2009 .00329 . x$

Niklasson, L. (2016). Challenges and Reforms of Local and Regional Governments. In J. Pierre (Ed.), The Oxford Handbook of Swedish Politics (pp. 399-413). Oxford: OUP.

Nyberg, L. (2008) . Översvämningar och riskhantering - en forskningsöversikt. Rapport Publ.nr MSB 0013-09. Stockholm: Myndigheten för samhällsskydd och beredskap

Oakerson, R. J., \& Parks, R. B. (1999). Citizen voice and public entrepreneurship: the organizational dynamic of a complex metropolitan country. In M. D. McGinnis (Ed.), Polycentricity and Local Public Economies: Readings from the Workshop in Political Theory and Policy Analysis (pp. 306-328). Ann Arbor: The University of Michigan Press.

Oakerson, R. J., \& Parks, R. B. (2011). The Study of Local Public Economies Multi-organizational, Multi-level Institutional Analysis and Development. Policy Studies Journal, 39(1), 147-167. doi:10.1111/j.1541-0072.2010.00400.x 
Olausson, P. M. (2012). Riskhantering genom nätverk: de svenska älvgrupperna. Paper presented the NORKOM, Olso University.

Olausson, P.M. \& Nyhlén, J. (forthcoming). Organization and decisionmaking in enforced networks: the river groups in northern Sweden. Journal of Contingencies and Crisis Management

Osborne, D., \& Gaebler, T. (1992). Reinventing Government: How the entrepreneurial spirit is transforming the public sector from schoolhouse to statehouse, city hall to the Pentagon. Reading, MA: William Patrick.

Ostrom, V. (1999). Polycentricity Part 1. In M. D. McGinnis (Ed.), Polycentricity and Local Public Economies: Readings from the Workshop in Political Theory and Policy Analysis (pp. 53-74). Ann Arbor: The University of Michigan Press.

Patton, M. Q. (1987). How to use qualitative methods in evaluation. Newbury Park, CA: Sage..

Peters, B. G. (1998). Managing Horizontal Government: The Politics of Co-Ordination. Public Administration, 76(2), 295-311. doi:10.1111/14679299.00102

Peters, B. G. (2015). Advanced Introduction to Public Policy. Cheltenham, UK: Edward Elgar.

Petersson, O. (2016). Rational Politics: Commissions of Inquiry and the Referral System in Sweden. In J. Pierre (Ed.), The Oxford Handbook of Swedish Politics (pp. 650-662). Oxford: OUP.

Petridou, E. (2014). Theories of the Policy Process: Contemporary Scholarship and Future Directions. Policy Studies Journal, 42, S12-S32. doi:10.1111/psj.12054

Petridou, E. (2017). Political entrepreneurship in Swedish: towards a (re)theorization of entrepreneurial agency (Doctoral dissertation). Mid Sweden University: Sundsvall.

Petridou, E., Narbutaité Aflaki, I., \& Miles, L. (2015). Unpacking the Theoretical Boxes of Political Entrepreneurship. In I. Narbutaité Aflaki, E. Petridou, and L. Miles (Eds.), Entrepreneurship in the Polis: Understanding Political Entrepreneurship (pp. 1-16). Burlington, VT: Ashgate.

Pierson, C. (2003). Learning from Labor? Welfare Policy Transfer between Australia and Britain. Commonwealth and Comparative Politics, 41(1), 77100. doi:10.1080/71399960

Renn, O., Klinke, A., \& van Asselt, M. (2011). Coping with Complexity, Uncertainty and Ambiguity in Risk Governance: A Synthesis. Ambio, 40(2), 231-246. doi:10.1007/\$13280-010-0134-0
Rhodes, R. A. W. (1997) Understanding Governance: Policy Networks, Governance, Reflexivity and Accountability. Administrative Theory and Praxis, 20 (3), pp. 394-396.

Rose, R. (1991). What Is Lesson-Drawing? Journal of Public Policy, 11(1), 3-30. doi:10.2307/4007336

Rose, R. (2005). Learning from Comparative Public Policy. London: Routledge.

Schneider, M., Teske, P., \& Mintrom, M. (1995). Public Entrepreneurs: Agents for Change in American Government. Princeton: Princeton University Press.

SMHI: Swedish Meteorological and Hydrological Institute (2015) "Översvämingar." http://www.smhi.se/kunskapsbanken/hydrologi/ oversvamningar-1.5949. Accessed on 5 March, 2016

Smith, A. (2004). Policy transfer in the development of UK climate policy. Policy and Politics, 32(1), 79-93. doi:10.1332/030557304772860067

SOU (1995). Utredningen om damsäkerket och höga flöden. [Investigation on the security of dams and high flows] Stockholm: Statens Offentliga Utredningar.

Sørensen, E., \&Torfing, J. (2009). Making Governance Networks Effective and Democratic through Metagovernance. Public Administration, 87(2), 234-258. doi:10.1111/j.1467-9299.2009.01753.x

Verduijn, S. (2015). Setting the Political Agenda: A Policy Entrepreneurial Perspective on Urban Development in the Netherlands. In I. Narbutaité Aflaki, E. Petridou, and L. Miles (Eds.), Entrepreneurship in the Polis: Understanding Political Entrepreneurship (pp. 55-72). Burlington, VT: Ashgate.

Windrum, P. (2008). Innovation and Entrepreneurship in Public Services. In P. Windrum and P. Koch (Eds.), Innovation in Public Sector Services: Entrepreneurship, Creativity and Management (pp. 3-10). Chelenham, UK: Edward Elgar.

Yin, R. K. (1994). Case study research: Design and methods (2nd ed.). Thousand Oaks, CA: Sage.

Zahariadis, N. (2007). The multiple streams framework: structure, limitations, prospects. In P. A. Sabatier (Ed.), Theories of the Policy Process (pp. 65-92). Boulder, CO: Westview. 